\title{
Effect of Artemisia judaica Essential Oil on Bacterial Biofilm and Its Mode of Action
}

\author{
Sameeh Al-Sarayreh ${ }^{1}$, Jehad Al-Shuneigat², Yousef Al-Saraireh³, Mahmoud Al-Qudah \\ 1, 2 Department of Biochemistry and Molecular Biology, Mutah University, Mutah, Jordan. ${ }^{3}$ Department of \\ Pharmacology, Mutah University, Mutah, Jordan. ${ }^{4}$ Department of Chemistry, Yarmouk University, Irbid, Jordan.
}

\section{ABSTRACT}

\section{BACKGROUND}

Drug resistance and failure of antibiotics to treat bacterial infections is the most challenging clinical and public health problem. There is ongoing research for new, safe and effective alternatives to antibiotics for the therapeutic management of bacterial infections. Essential oils are one of the outcomes of such type of research. This study was conducted to evaluate the effect of Artemisia judaica essential oil against the bacterial \& the biofilm activity and to study its mode of action.

\section{METHODS}

Minimum biofilm inhibitory concentration (MBIC) susceptibility assays were performed using a biofilm inoculator with a 96-well plate with peg lid. Minimum inhibitory concentration (MIC) was performed in normal microtiter plates using a twofold dilution series.

\section{RESULTS}

The values of the minimum inhibitory concentration (MIC), the minimum bactericidal concentration (MBC), minimum biofilm inhibitory concentration (MBIC) and the minimum biofilm eradication concentration (MBEC) were in the range of $0.25-1 \mathrm{mg}$ / mL, $1.0-4 \mathrm{mg} / \mathrm{mL}, 0.50-2 \mathrm{mg} / \mathrm{mL}$ and $1.0-8 \mathrm{mg} / \mathrm{mL}$, respectively. There was increase in the leakage of $\mathrm{K}^{+}$and cellular components through the membrane of the tested bacteria under the effect of essential oil of Artemisia judaica proving that the cell membrane was the site of action of Artemisia judaica. This was shown by its inhibitory effect on the Staphylococcus epidermidis (ATCC 35984) during initial adherence at sub-inhibitory concentrations.

\section{CONCLUSIONS}

The essential oil of Artemisia judaica had the ability to overcome all tested bacterial resistance and also prevents the formation of biofilm. The site of action of Artemisia judaica essential oil was the cell membrane and cell wall.

\section{KEY WORDS}

Antibacterial, Antibiofilm, Artemisia judaica, Mode of Action, Essential Oil
Corresponding Author:

Sameeh Al-Sarayreh,

Department of Biochemistry and

Molecular Biology,

Faculty of Medicine,

Mutah University,

Mutah - 61710, Jordan,

E-mail: sameeh_sarayreh@mutah.edu.jo

DOI: $10.14260 /$ jemds $/ 2021 / 367$

How to Cite This Article:

Al-Sarayreh S, Al-Shuneigat J, Al-Saraireh $Y$, et al. Effect of artemisia judaica essential oil on bacterial biofilm and its mode of action. J Evolution Med Dent Sci 2021;10(23): 1777-1783, DOI:

$10.14260 /$ jemds/2021/367

Submission 31-12-2020,

Peer Review 15-04-2021,

Acceptance 21-04-2021,

Published 07-06-2021.

Copyright (C) 2021 Sameeh Al-Sarayreh et al. This is an open access article distributed under Creative Commons Attribution License [Attribution 4.0 International (CC $B Y 4.0)]$ 


\section{BACKGROUND}

Microbial cells that can produce extracellular polymeric substance (EPS) containing water, polysaccharides, proteins, deoxyribonucleic acid and ribonucleic acid (DNA and RNA), can adhere to and embed within surfaces.$^{27}$ EPS makes about $90 \%$ of biofilms. ${ }^{13}$ Bacterial biofilm is infectious and causes about $65 \%$ of all microbial infections and $80 \%$ of chronic and recurrent microbial infections. ${ }^{5}$ Microbes form biofilm as a strategy for survival to withstand unfavourable environmental conditions like starvation, low $\mathrm{pH}$ and desiccation. Further, it protects them from the host immune system and antibiotic treatment. ${ }^{6}$ Biofilm is highly resistant to antibiotics due to low accessibility of antibiotics and immune system to biofilm organisms, slow growth and reproduction of biofilm cells, formation of persisters and high activity of efflux pumps. ${ }^{11}$

Biofilm can occur on different surfaces include teeth, lungs of cystic fibrosis patients, contact lenses, heart valves, middle ear of patients with persistent otitis, prosthetic joints, intravenous catheters and stents. ${ }^{21}$ Bacterial biofilm causes chronic infections characterized by persistent inflammation and tissue damage including endocarditis, cystic fibrosis and osteomyelitis. Financially, biofilm causes a loss of $\$ 11$ billion in USA alone. ${ }^{6}$ The emerging drug resistance of bacteria to commonly used antibiotics have become a major health problem. Some bacteria have developed resistance to nearly all currently used antibiotics. ${ }^{25}$ Hence, there is a need to explore new therapeutic agents to provide efficient and affordable alternatives to antibiotics to rectify the emerging drug resistance. ${ }^{3}$ In recent years, there has been an increased interest towards essential oils.

Essential oils are hydrophobic volatile compounds that are extracted from different parts of aromatic plants. Essential oils have been included as traditional medicine for many years in treating different diseases. ${ }^{24}$ Essential oils are secondary metabolites that reported to possess antibacterial, antifungal, antiviral, antiparasite and antioxidant properties. In addition, essential oils are used in cosmetic applications, agricultural and food industries. ${ }^{10}$ Essential oils contain a variety of volatile molecules that can be divided into two groups, the hydrocarbon compounds and oxygenated compounds. Hydrocarbon compounds are made up of terpenes including monoterpenes and sesquiterpenes while the oxygenated compounds are mainly esters, aldehydes, alcohols, ketones and phenols. ${ }^{12}$ The genus Artemisia comprises more than 500 species, many of which, are important as aromatic and medicinal plants and are used in traditional medicine, cosmetics and pharmaceutical industry. ${ }^{1}$ In folk medicine, Artemisia judaica is widely used in treatment of wound inflammations, atherosclerosis, stomach-ache, diabetes, gastro-intestinal disorders, fungal infections and others. ${ }^{4}$

This study was conducted to evaluate the effect of Artemisia judaica essential oil against the bacteria and the biofilm and study its mode of action.

\section{METHODS}

\section{Essential Oil of Artemisia judaica}

The aerial plant parts of Artemisia judaica were collected at the full flowering stage during April 2019 from surrounding regions of the Mutah, Al-Karak city, Jordan. The chemical composition of the essential oil of Artemisia judaica was previously published. ${ }^{4}$ Its major component includes: E-ethyl cinnamate, piperitone, chrysanthenone, (Z)- Ethyl cinnamate, davanone, Juniperol, Z-Tagetone, isophorone, cis-Piperitol, isolongifolan-Z- $\alpha$-ol, trans-Muurola-4 (14) 5-diene, 2, 6Dimethyl phenol, E-Jasmonyl acetate, $\alpha$-Terpinyl acetate, $\gamma$ terpineol, p-cymene, cis- Sabinene hydrate, cisDihydrocarvone, Isobornyl acetate, 2- (1Z)-propenylphenol and caryophyllene acetate in the following percentages 16.01 $\%, 10.1 \%, 6.94 \%, 6.31 \%, 4.66 \%, 4.56 \%, 4.34 \%, 3.84 \%, 3.44$ \%, $2.93 \%, 2.63 \%, 2.53 \%, 2.19 \%, 1.58 \%, 1.5 \%, 1.47 \%, 1.37$ $\%, 1.32 \%, 1.32 \%, 1.3 \%$ and $1.12 \%$, respectively. The major components of the essential oil were oxygenated monoterpene, oxygenated sesquiterpene, sesquiterpene, hydrocarbon, monoterpene hydrocarbon, monoterpene hydrocarbon ester and others (43.27\%, $16.72 \%, 4.46 \%, 2.16$ $\%, 26.23 \%$, and $4.53 \%$ respectively).

The following experiments were conducted between $1^{\text {st }}$ March 2020 and 20th August 2020.

\section{Maintenance and Preparation of Cultures}

Six different bacterial strains were included for evaluating the effect of essential oil of Artemisia judaica on the bacterial biofilm, those strains include Staphylococcus epidermidis (ATCC 35984), the non-biofilm forming strain Staphylococcus epidermidis (ATCC 12228), Methicillin-resistant Staphylococcus aureus (MRSA) (ATCC 43300), Escherichia coli (ATCC 25922), methicillin-susceptible Staphylococcus aureus (MSSA) (ATCC 25923) and Pseudomonas aeruginosa (ATCC 27853). The six bacterial strains were cultured and stored at 2 - $4^{\circ} \mathrm{C}$ on tryptone soya agar (Oxoid, Hampshire, UK) with frequent sub-culturing at 3 - 4 weeks intervals or at the time of need.

\section{Minimum Inhibitory Concentration (MIC)}

MIC was determined according to the method of Rachid et al. ${ }^{23}$ a 96 well broth microtiter was used. Briefly, a twofold serial dilution of $0.125 \mathrm{mg} / \mathrm{mL}, 0.250 \mathrm{mg} / \mathrm{mL}, 0.5 \mathrm{mg} / \mathrm{mL}, 1 \mathrm{mg} /$ $\mathrm{mL}, 2 \mathrm{mg} / \mathrm{mL}, 4 \mathrm{mg} / \mathrm{mL}, 8 \mathrm{mg} / \mathrm{mL}$, and $16 \mathrm{mg} / \mathrm{mL}$ concentration of essential oil of Artemisia judaica in tryptic soy broth (TSB) (Oxoid, Hampshire, UK). Inoculated bacterial cells in TSB $(100 \mathrm{~mL})$ were incubated overnight $(0 / \mathrm{N})$ at $37^{\circ} \mathrm{C}$ to grow till the mid-log phase [OD reading at $600 \mathrm{~nm}\left(\mathrm{OD}_{600}\right)$ reached 0.6 approximately], then diluted to $1 \times 10^{6} \mathrm{cfu} / \mathrm{m}$ and $100 \mu \mathrm{L}$ were added and mixed with the essential oil of Artemisia judaica in the wells of the microtiter plate, finally, incubated aerobically at $37^{\circ} \mathrm{C}$ for $24 \mathrm{~h}$. The MIC was defined as the minimal concentration of the essential oil of Artemisia judaica that can inhibit the bacterial strain visible growth. The three independent experiments carried out in triplets were used to determine MIC. Both gentamicin and media containing only essential oil without any bacterial strain were used as positive and negative controls, respectively. The selection of gentamicin was based on its ability to treat gram positive as well as gram negative bacterial infections. 


\section{Minimum Bactericidal Concentration (MBC)}

MBC was defined as the lowest concentration of essential oil for reducing and killing almost all initial inoculum (99.9\%), ${ }^{18}$ for determining its values, MIC was applied to confirm the wells of non-apparent bacterial growth, then, $30 \mu \mathrm{L}$ was taken from each well to be plated on tryptone soya agar (TSA) and the plates were incubated for $48 \mathrm{~h}$ at $37^{\circ} \mathrm{C}$. The used concentrations of the essential oil were $0.125 \mathrm{mg} / \mathrm{mL}, 0.250$ $\mathrm{mg} / \mathrm{mL}, 0.5 \mathrm{mg} / \mathrm{mL}, 1 \mathrm{mg} / \mathrm{mL}, 2 \mathrm{mg} / \mathrm{mL}, 4 \mathrm{mg} / \mathrm{mL}, 8 \mathrm{mg}$ $/ \mathrm{mL}$, and $16 \mathrm{mg} / \mathrm{mL}$. Both gentamicin and media containing only essential oil without any bacterial strain were used as positive and negative controls, respectively.

\section{Minimum Biofilm Inhibitory Concentration (MBIC) Assay}

It was used for the biofilm susceptibility assays (Innovotech, Inc., Edmonton, $\mathrm{AB}$, Canda) in a 96 well microtiter biofilm inoculator plate according to the method described by Ceri et al. 8

In TSB, the strains of bacteria were cultured $\mathrm{O} / \mathrm{N}$ (Oxoid, Hampshire, UK), then, diluted to give $1 \times 10^{6} \mathrm{cfu} / \mathrm{mL}$ final concentration. To each well of 96-well MBEC biofilm inoculators, $150 \mu \mathrm{L}$ of inoculum was added with fitting the peg lid on the plates. Then, on pegs, the biofilms were formed after incubation at $37^{\circ} \mathrm{C}$ for 24 hours. The peg lid was rinsed 3 times in phosphate-buffered saline (PBS) (Sigma Aldrich) for removing the non-adherent cells, then, a 96-well plate containing the essential oil in serial dilutions $0.125 \mathrm{mg} / \mathrm{mL}$, $0.250 \mathrm{mg} / \mathrm{mL}, 0.5 \mathrm{mg} / \mathrm{mL}, 1 \mathrm{mg} / \mathrm{mL}, 2 \mathrm{mg} / \mathrm{mL}, 4 \mathrm{mg} / \mathrm{mL}$, $8 \mathrm{mg} / \mathrm{mL}$, and $16 \mathrm{mg} / \mathrm{mL}$ ) was used for the transfer of the peg lid. After the incubation of the pegs of the microtiter plate with the essential oil for $24 \mathrm{~h}$ at $37^{\circ} \mathrm{C}$, the pegs were rinsed 3 times with PBS and placed in a recovery plate (fresh 96-well microtiter plate containing $100 \mathrm{~mL}$ of TSB). The bacteria were removed from the pegs and sonicated for 5 min in Decon F51 006 sonicator at maximum speed. The standard lids were used to replace the peg lids. Pre- and post-incubation, the $\mathrm{OD}_{650}$ was measured for 6 hours at $37^{\circ} \mathrm{C}$. The three independent experiments carried out in triplets were used for biofilm susceptibility assays for each bacterial strain. The absence of biofilm was confirmed by the value of $0.5 \mathrm{OD}_{650}$. The MBIC was defined as the minimal concentration of the essential oil of Artemisia judaica that can inhibit the bacterial strain visible growth which was confirmed by the absence of any increase in OD reading versus the initial one. A significant change was considered when there was shift of more than two doubling dilutions in the susceptibility in either direction. Gentamicin and media containing only essential oil without any bacterial strain were used as positive and negative controls, respectively.

\section{Minimum Biofilm Eradication Concentration (MBEC)}

$30 \mu \mathrm{L}$ from each well which showed no apparent growth, confirmed by the determined values of MBIC was plated on TSA agar, then, incubated for $48 \mathrm{~h}$ at $37^{\circ} \mathrm{C}$ to determine MBEC. The MBEC was defined as the lowest concentration of essential oil showing no growth of the bacteria on the TSA plates. Gentamicin was used as a positive control, while, the media containing only essential oil without any bacterial strain was used as a negative control.

\section{Leakage of Potassium Ion}

Kalium / Potassium kit (Quantofix, Macherey-Nagel GmbH \& Co. KG, Duren, Germany) was used to determine $\mathrm{K}^{+}$ion leakage. Pseudomonas aeruginosa (ATCC 27853), Staphylococcus epidermidis (ATCC 35984), Escherichia coli (ATCC 25922) and Methicillin-resistant Staphylococcus aureus (MRSA) (ATCC 43300) were exposed to essential oils of $0.1 \mathrm{~g} /$ mL MIC value in sterile peptone water. The concentration of extracellular potassium $\mathrm{K}^{+}$was measured at time intervals of $0,30,60,90,120$, and 240 minutes. An Enteromorpha linza essential oils AEO free culture flask was employed as a control. Results were expressed as the amount of free $\mathrm{K}^{+}$ion $(\mathrm{mg} / \mathrm{L}$ ) in the suspension of bacteria at each time interval. Gentamicin was the positive control, while, the negative control was only media and essential oil without bacteria.

\section{Integrity of the Cell Membrane (Release of Cellular Material)}

The cell membrane, the cellular component that is holding the different contents of the cell together and protecting it from extracellular environment. Thus, the cell membrane damage is indicated by cellular materials release especially DNA, RNA and proteins extra cellularly. At the MIC concentration, the essential oils were added to $2 \mathrm{~mL}$ of the Methicillin-susceptible Staphylococcus aureus (MSSA) (ATCC 25923), Staphylococcus epidermidis (ATCC 12228) and Escherichia coli (ATCC 25922) $\left(10^{7} \mathrm{cfu} / \mathrm{mL}\right)$ in sterilized peptone water at concentration of $0.1 \mathrm{~g} / 100 \mathrm{~mL}$, then, incubated at $37^{\circ} \mathrm{C}$. After treatment time intervals of $0,30,60,90,120,180$ and 240 minutes, then, the cells were collected and centrifuged at $3000 \mathrm{rpm}$. The spectrophotometer was used for measuring the $260 \mathrm{~nm} \mathrm{UV}$ absorbance of the supernatant, the used control was a tube containing sterilized peptone water free of bacteria. ${ }^{27}$ The positive control used was gentamicin while the negative control was only media and essential oil without bacteria.

\section{Adherence of Bacterial Cells to Polystyrene}

The method of Heilmann et al. ${ }^{16}$ was used to determine the initial adherence of methicillin-resistant Staphylococcus epidermidis (ATCC 35984) to polystyrene. Briefly, an 0 / N grown bacteria at $37^{\circ} \mathrm{C}$ in $10 \mathrm{ml}$ TSB was diluted $1: 100$ in the essential oil of Artemisia judaica contained in fresh TSB at the needed concentration. 1 / 10 of MIC, 1 / 2 of MIC, the full MIC and five times the MIC were the used concentrations of essential oil. The positive control used was gentamicin while the negative control was only media and bacteria but without essential oil.

$5 \mathrm{~mL}$ of each bacterial suspension was incubated at $37^{\circ} \mathrm{C}$ for $30 \mathrm{~min}$ in a Petri dish. Each dish was washed in $5 \mathrm{~mL}$ PBS for five times, then, air dried and stained in $0.4 \%$ crystal violet for $1 \mathrm{~min}$. The adhered cells number was counted in 20 fields view under the microscope (CETI 60243T UK). 1 / 10 of MIC, 1 / 2 of MIC, the full MIC and five times the MIC were the used concentrations of essential oil. The calculated total cells number adhered per $\mathrm{cm}^{2}$ examined was used to express the cellular adherence. The test for assaying the concentration of each essential oil of Artemisia judaica was carried out in triplicate and the adherence of the treated cells was compared 
to the untreated ones. Assays were done three times on different days and the result obtained was the same in each occasion.

\section{Statistical Analysis}

Statistical Package for the Social Sciences (SPSS) package for Windows (version 15, Chicago, IL, and USA) was used for statistical analyses of the obtained results. The experiments were performed in triplicate. The obtained results were expressed as mean \pm SD.

\section{RESULTS}

\section{MIC and MBC Results}

Table 1 shows the results of MIC and MBC of the essential oil of Artemisia judaica. The values of MIC were $0.25-1 \mathrm{mg} / \mathrm{mL}$ range. Regarding MIC, Escherichia coli (ATCC 25922) with MIC value of $0.25 \mathrm{mg} / \mathrm{mL}$ was the most susceptible isolate and the strains of methicillin-resistant Staphylococcus aureus (MRSA) (ATCC 43300) and Pseudomonas aeruginosa (ATCC 27853) with MIC value of $1 \mathrm{mg} / \mathrm{mL}$ were the most resistant isolates.

The range of MBC values was $1.0-4 \mathrm{mg} / \mathrm{mL}$. The most susceptible isolate in MBC was Staphylococcus epidermidis (ATCC 12228) with MBC of $1.0 \mathrm{mg} / \mathrm{mL}$ while, Pseudomonas aeruginosa (ATCC 27853) at $4 \mathrm{mg} / \mathrm{mL} \mathrm{MBC}$ value was the most resistant $\mathrm{MBC}$. The values of $\mathrm{MBC}$ were higher than those for MIC for all tested strains.

\begin{tabular}{|c|c|c|c|}
\hline Isolate & Isolate Name & MIC mg & MBC mg \\
\hline Number & & $\mathbf{m L}$ & $/ \mathbf{m L}$ \\
\hline 1 & Staphylococcus epidermidis (ATCC 35984) & 0.50 & 2 \\
\hline 2 & $\begin{array}{l}\text { Methicillin-susceptible Staphylococcus aureus } \\
\text { (MSSA) (ATCC 25923) }\end{array}$ & 0.5 & 2 \\
\hline 3 & $\begin{array}{c}\text { Methicillin-resistant Staphylococcus aureus } \\
\text { (MRSA) (ATCC 43300) }\end{array}$ & 1.00 & 2 \\
\hline 4 & Pseudomonas aeruginosa (ATCC 27853) & 1.00 & 4 \\
\hline 5 & Escherichia coli (ATCC 25922) & 0.25 & 2 \\
\hline 6 & Staphylococcus epidermidis (ATCC12228) & 0.50 & 1 \\
\hline Control & Gentamicin against MRSA (ATCC 43300) & $\begin{array}{l}0.500 \pm \\
0.05\end{array}$ & $\begin{array}{r}2.0 \pm \\
0.025\end{array}$ \\
\hline Control & Gentamicin against $P$. aeruginosa (ATCC 27853) & $\begin{array}{c}0.125 \pm \\
0.05\end{array}$ & $0.5 \pm 0.01$ \\
\hline
\end{tabular}

\begin{tabular}{|c|c|c|c|}
\hline \multirow{2}{*}{$\begin{array}{l}\text { Isolate } \\
\text { Number }\end{array}$} & \multirow{2}{*}{ Isolate Name } & \multicolumn{2}{|c|}{ MBIC mg / MBEC mg } \\
\hline & & $\mathrm{mL}^{\circ}$ & $/ \mathbf{m L}$ \\
\hline 1 & Staphylococcus epidermidis (ATCC 35984) & 2 & 4 \\
\hline 2 & $\begin{array}{c}\text { Methicillin-susceptible Staphylococcus } \\
\text { aureus (MSSA) (ATCC 25923) }\end{array}$ & 1 & 2 \\
\hline 3 & $\begin{array}{c}\text { Methicillin-resistant Staphylococcus aureus } \\
\text { (MRSA) (ATCC 43300) }\end{array}$ & 2 & 4 \\
\hline 4 & Pseudomonas aeruginosa (ATCC 27853) & 2 & 8 \\
\hline 5 & Escherichia coli (ATCC 25922) & 1 & 4 \\
\hline 6 & Staphylococcus epidermidis (ATCC 12228) & 0.50 & 1 \\
\hline Control & Gentamicin against MRSA (ATCC 43300) & $1.00 \pm 0.15$ & $2.0 \pm 0.12$ \\
\hline Control & $\begin{array}{c}\text { Gentamicin against } P \text {. aeruginosa (ATCC } \\
27853 \text { ) }\end{array}$ & $0.500 \pm 0.05$ & $1.0 \pm 0.05$ \\
\hline & $\begin{array}{l}\text { The Values of MBIC and MBEC of Ar } \\
(\mathrm{mg} / \mathrm{mL}) \text { for the Bacterial Isol }\end{array}$ & $\begin{array}{l}\text { temisia jud } \\
\text { ates }\end{array}$ & laica \\
\hline
\end{tabular}

Table 2 shows that the values of MBIC were in $0.50-2 \mathrm{mg}$ / $\mathrm{mL}$ range. Staphylococcus epidermidis (ATCC 12228) at value of $0.50 \mathrm{mg} / \mathrm{mL}$ MBIC was the most susceptible, which can be explained by being a non-biofilm forming bacteria. While, methicillin-resistant Staphylococcus aureus (MRSA) (ATCC 43300), Staphylococcus epidermidis (ATCC 35984) and
Pseudomonas aeruginosa (ATCC 27853) at $2 \mathrm{mg} / \mathrm{mL} \mathrm{MBIC}$ value were the most resistant isolates.

The MBEC values were in the range of $1.0-8 \mathrm{mg} / \mathrm{mL}$. The most susceptible one was Staphylococcus epidermidis (ATCC 12228) with MBEC of $1.0 \mathrm{mg} / \mathrm{mL}$, while the most resistant was Pseudomonas aeruginosa (ATCC 27853) at $8 \mathrm{mg} / \mathrm{mL}$ MBEC value. The values of MBEC were higher comparable to MBIC values for all tested strains.

\section{$\mathrm{K}^{+}$Ion Leakage}

The permeability of cell membrane was based upon $\mathrm{K}+$ ions leakage, the following bacterial strain treated with the essential oil of Artemisia judaica were used for that: Methicillin-resistant Staphylococcus aureus (MRSA) (ATCC 43300), Staphylococcus epidermidis (ATCC 35984), Escherichia coli (ATCC 25922) and Pseudomonas aeruginosa. In all studied bacterial strains, at the MIC concentration, it was observed that there was a sharp increase in the leakage of $\mathrm{K}^{+}$ions from $50 \mu \mathrm{M}$ up to $300 \mu \mathrm{M}$ extracellularly (Figure 1) and the leakage was observed to be increased with the incubation period increase (Figure 1)

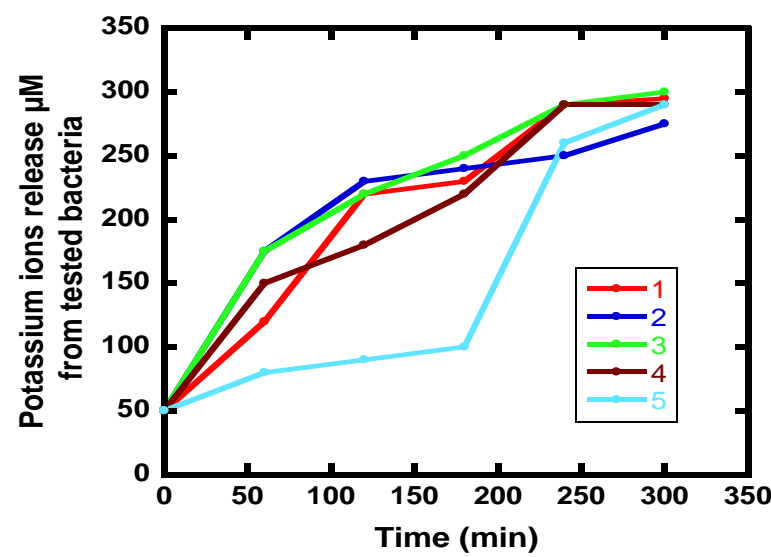

Figure 1. K+ Ions Release ( $\mu$ M) from Tested Bacteria after Treatment with Artemisia judaica Essential Oil as:

1. Staphylococcus epidermidis (ATCC 35984)
2. 2-MRSA (ATCC 43300)
3. Pseudomonas aeruginosa (ATCC 27853)
4. Escherichia coli (ATCC 25922)
5. Gentamicin (Reference Compound) against Methicillin-Resistant
Staphylococcus aureus (MRSA) (ATCC 43300)

The Release of Cellular Material as an Indicator for the Cell Membrane Integrity

The extracellularly release of the cellular contents including the nucleic acids (DNA and RNA) is another indicator for the cell membrane damage. Upon treating Methicillin-susceptible Staphylococcus aureus (MSSA) (ATCC 25923), Staphylococcus epidermidis (ATCC 12228) and Escherichia coli (ATCC 25922), with the essential oils of Artemisia judaica at MIC concentration, the $260 \mathrm{~nm}$ absorption was continuously increased over the incubation time which was correlated positively with the time of exposure in all studied bacterial strains (Figure 2). 


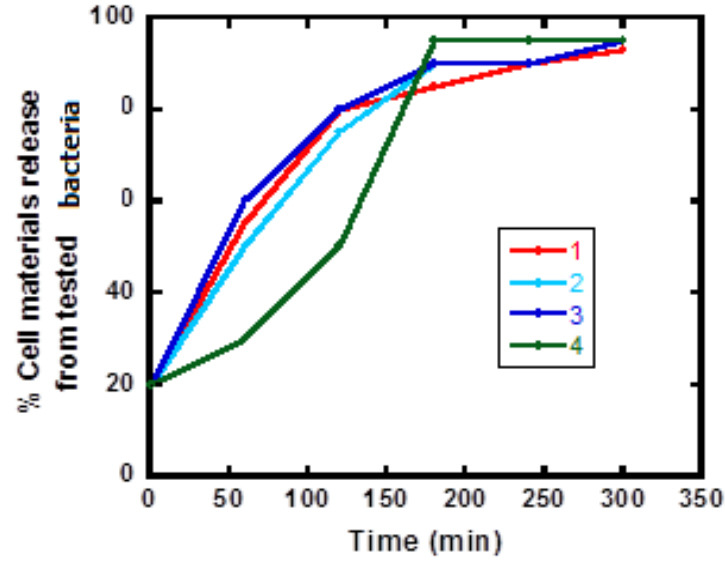

Figure 2. The Release of Cellular Material from Tested Bacteria afte Treatment with Artemisia judaica Essential Oil as:

Methicillin-Susceptible Staphylococcus aureus (MSSA) (ATCC 25923), Staphylococcus epidermidis (ATCC 12228), Escherichia coli (ATCC 25922) and Gentamicin (Reference Compounds) against Pseudomonas aeruginosa (ATCC 27853)

\section{Adherence of Bacterial Cells to Polystyrene}

The OD 600 and $\mathrm{OD}_{490}$ were used for measuring the planktonic growth and biofilm growth respectively. The studied concentrations of essential oil were 1 / 10 of MIC, 1 / 2 MIC and the full MIC concentration. It was noticed upon its addition to polystyrene Petri dishes containing a culture suspension of Staphylococcus epidermidis (ATCC 35984) strain that there was reduction in the number of adherent bacterial cells to the polystyrene surface after an incubation period of 30 minutes (Figure 3). The increase in the concentration of the essential oil of Artemisia judaica was accompanied by the decrease in the number of adherent bacterial cells.

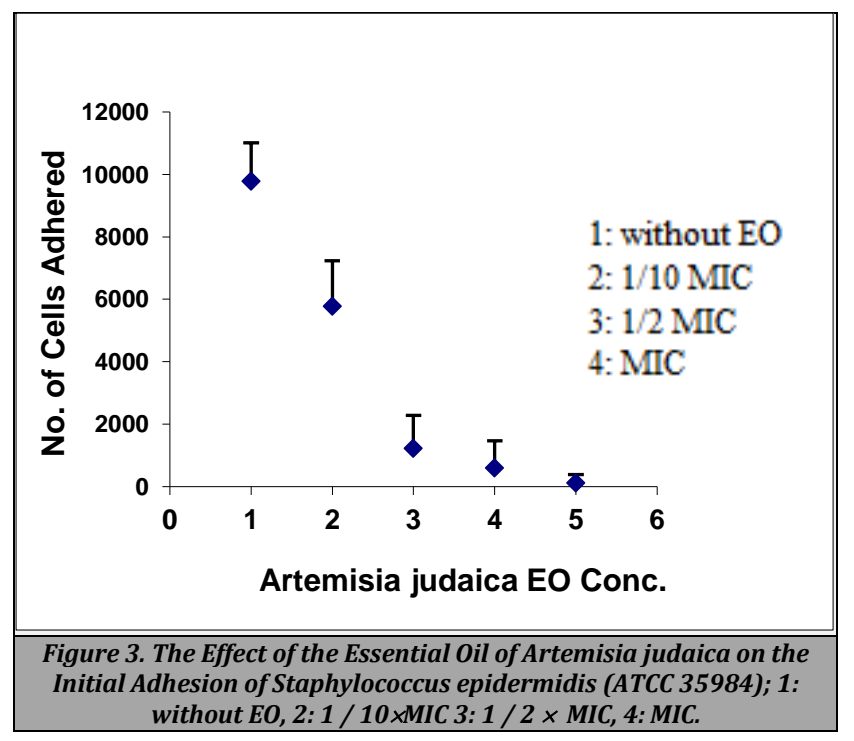

\section{DISCUSSION}

Microbial biofilms pose a challenge in clinical world as it causes infections untreatable and prolongs the duration of infections. It is generally accepted that $99 \%$ of all microbes form biofilm as a strategy for survival from their harsh environmental conditions. ${ }^{14}$ The hallmark of biofilm infections is extreme resistance to antibiotics and ability to evade the host defense mechanisms. Bacterial biofilm causes chronic infections characterized by persistent inflammation and tissue damage. It is estimated that $65-80 \%$ of microbial infections are associated with biofilms. ${ }^{17}$

There are various infections due to bacterial biofilms which include chronic sinusitis, wound infection, chronic otitis media, osteomyelitis, infection of the central nervous system shunt, pacemaker infection, cochlear implant infection, catheter infection, urinary stent infection, chest infection in patients with cystic fibrosis etc. ${ }^{14}$ Failure of antibiotic treatment in eradication of bacterial biofilm led researchers to look for alternatives. The success of the essential oils in treating different diseases was stated in various studies, while, the antibiotics failed. ${ }^{2}$

Essential oils are complex mixtures of a wide diversity of components. The essential oil of Artemisia judaica has 53 components. The antimicrobial activity of essential oils is associated their composition, configuration and their possible interaction. The effect of essential oil is a synergism of its combined ingredients. ${ }^{26}$ Thus, the antimicrobial activity of essential oil is not attributable to a single mechanism but to multi mechanisms that can affect both the cell membrane and the cytoplasm. However, cell wall and membrane remain the primary targets for essential oils. ${ }^{22}$

The cell membrane is essential for cell protection and in keeping a fixed environment inside the cell, nutrients transport, controlling the turgor pressure, maintaining the energy status of the cell and for metabolic regulation. ${ }^{15}$ Essential oils are hydrophobic thus they can pass through the lipid layer of the membrane and cause disruption of the phospholipid bilayer, damage and alterations to membrane structure and function. They also interfere with proteins in the cell wall.9,19 Moreover, essential oils can destroy membrane enzymes and inhibit electron transport system which could lead to membrane permeability alterations and destruction. All these changes lead to cell membranes destruction and cell death. ${ }^{22}$

In the current study, the essential oil of Artemisia judaica essential oil was shown to be able for overcoming the resistance exerted by all studied bacterial strains. The values of MIC, MBC, MBIC and MBEC were in the ranges of $0.25-1 \mathrm{mg}$ / mL, $1.0-4 \mathrm{mg} / \mathrm{mL}, 0.50-2 \mathrm{mg} / \mathrm{mL}$ and $1.0-8 \mathrm{mg} / \mathrm{mL}$, respectively. According to their structure, the active compounds in essential oils can be divided into four groups: terpenoids, terpenes, phenylpropenes and other compounds. ${ }^{7}$ The activity of terpenoids, such as piperitone which makes $10.1 \%$ in Artemisia judaica essential oil, has been linked to their functional groups. Phenylpropenes are synthesized from the amino acid phenylalanine and normally they constitute a relatively small part of essential oils examples eugenol vanillin and safrole. ${ }^{7}$ Terpenes such as p-Cymene that makes $1.47 \%$ in Artemisia judaica essential oil also shows antibacterial activity. P-Cymene shows a high affinity for the cell membrane causing its expansion. ${ }^{20}$ Additionally, it affects the membrane potential of the intact cells causing a decrease in their motility because the flagellar movement requires the proton motive force..$^{22}$

The results of the current study showed that Artemisia judaica essential oils caused elevated release of cell materials especially DNA and RNA to outside cell in all tested bacterial 
strains. It also caused a marked increase in $\mathrm{K}^{+}$ions with appositive correlation to the prolonged incubation time. These results indicate a damage in cell membrane and wall caused by Artemisia judaica essential oils that led to extracellular leakage of cell materials and potassium ions. Moreover, Artemisia judaica essential oil reduced the adhered bacteria to polystyrene Petri dishes. The reduction in the number of adherent bacterial cells to the polystyrene may be attributed to the effect of the essential oil of Artemisia judaica essential in the alteration of the responsible factors for adherence on the bacterial cell surface. This again proved that the site of action of Artemisia judaica essential oils is cell wall and cell membrane.

\section{CONCLUSIONS}

Artemisia judaica essential oil showed high activity against all tested bacteria and was able to prevent the formation of biofilm. The site of action of Artemisia judaica essential oil was the cell membrane and cell wall.

Data sharing statement provided by the authors is available with the full text of this article at jemds.com.

Financial or other competing interests: None.

Disclosure forms provided by the authors are available with the full text of this article at jemds.com.

\section{REFERENCES}

[1] Abad MJ, Bedoya LM, Apaza L, Bermejo P (2012) The artemisia L. Genus: a review of bioactive essential oils. Molecules (Basel, Switzerland) 17: 2542 - 2566.

[2] Al - Shuneigat J, Al - Sarayreh S, Al-Saraireh Y, Al - Qudah M, Al - Tarawneh I, Al - Dalaen S (2014) Chemical composition and antimicrobial activity of the essential oil of wild Thymus vulgaris grown in South Jordan.IOSR Journal of Pharmacy and Biological Sciences (IOSR - JPBS) 9:78- 82.

[3] Al - Shuneigat J, Yu JQ, Beale P, Fisher K, Huq F (2010) Studies on Two New Mixed Ligand Platinum Compounds with a Trans - Geometry.Journal of Medicinal Chemistry1:321 - 328.

[4] Al - Sarayreh S, Al - Shuneigat J, Al - Qudah M, Al-Saraireh Y, Al - Tarawneh I (2020) Chemical composition and antioxidant activity of essential oil of Artemisia judaica $\mathrm{L}$. IJBPAS 9: 1 - 12

[5] Atanaki FF, Behrouzi S, Ariaeenejad S, Boroomand A, Kavousi K (2020) BIPEP: Sequence - based Prediction of Biofilm Inhibitory Peptides Using a Combination of NMR and Physicochemical Descriptors. ACS Omega 5: 7290 7297.

[6] Banerjee D, Shivapriya PM, Gautam PK, Misra K, Sahoo AK, Samanta SK (2020) A Review on Basic Biology of Bacterial Biofilm Infections and Their Treatments by Nanotechnology - Based Approaches. ProcNatlAcadSci India Sect B BiolSci 90: 243 - 259.

[7] Burcul F, Blazevic I, Radan M, Politeo O (2020) Terpenes, Phenylpropanoids, Sulfur and Other Essential Oil Constituents as Inhibitors of Cholinesterases. Curr Med Chem 27:4297 - 4343.
[8] Ceri H, Olson M, Morck D, Storey D, Read R, Buret A, Olson B (2001) The MBEC Assay System: multiple equivalent biofilms for antibiotic and biocide susceptibility testing. Methods Enzymol 337: 377 - 385.

[9] Chouhan S, Sharma K, Guleria S (2017) Antimicrobial Activity of Some Essential Oils - Present Status and Future Perspectives. Medicines (Basel, Switzerland) 4:1 - 21.

[10] Da Silva JAT, Yonekura L, Kaganda J, Mookdasanit J, Nhut DT, Afach G (2005) Important Secondary Metabolites and Essential Oils of Species Within the Anthemideae (Asteraceae). Journal of Herbs Spices \& Medicinal Plants 11: 1 - 46

[11] Dawan J, Wei S, Ahn J (2020) Role of antibiotic stress in phenotypic switching to persister cells of antibiotic resistant Staphylococcus aureus. Ann Microbiol 70: 1 - 8.

[12] Dhifi W, Bellili S, Jazi S, Bahloul N, Mnif W (2016) Essential Oils' Chemical Characterization and Investigation of Some Biological Activities: A Critical Review. Medicines (Basel, Switzerland) 3: 1 - 16.

[13] Flemming H - C and Wingender J (2010) The biofilm matrix. Nature Reviews Microbiology 8: 623 - 633.

[14] Gebreyohannes G, Nyerere A, Bii C, Sbhatu, DB (2019) Challenges of intervention, treatment, and antibiotic resistance of biofilm - forming microorganisms. Heliyon 5:1 - 7.

[15] Haswell ES, Verslues PE (2015) The ongoing search for the molecular basis of plant osmosensing. The Journal of general physiology 145: 389 - 394.

[16] Heilmann C, Gerke C, Premington FP, Gotz F (1996) Characterization of Tn917 insertion mutant of Staphylococcus epidermidisaffected in biofilm formation. Infect Immun 64: 277 - 282.

[17] Jamal M, Ahmad W, Andleeb S, Jalil F, Imran M, Nawaz MA, Hussain T, Ali M, Rafiq M, Kamil MA (2018) Bacterial biofilm and associated infections. J Chin Med Assoc 8:7 11.

[18] Jardak M, Elloumi - Mseddi J, Aifa S, Mnif S (2017) Chemical composition, anti - biofilm activity and potential cytotoxic effect on cancer cells of RosmarinusofficinalisL. essential oil from Tunisia. Lipid Health Dis 16: 1 - 10.

[19] Kim SA, Rhee MS (2016) Highly enhanced bactericidal effects of medium chain fatty acids (caprylic, capric, and lauric acid) combined with edible plant essential oils (carvacrol, eugenol, $\beta$ - resorcylic acid, trans cinnamaldehyde, thymol, and vanillin) against Escherichia coli 0157: H7. Food Control 60: 447 - 454.

[20] Mabrouk MI, El - Hendawy HM, Basha AM, Saleh NM (2016) Prevalence, antibiotic and oil resistance pattern of some bacterial isolates from burns. Journal of Applied Pharmaceutical Science 6:123 - 130.

[21] Magana M, Sereti C, Ioannidis A, Mitchell CA, Ball AR, Magiorkinis E, Chatzipanagiotou S, Hamblin MR, Hadjifrangiskou M, Tegos GP (2018) Options and Limitations in Clinical Investigation of Bacterial Biofilms. Clinical Microbiology Reviews 31: 1 - 49.

[22] Nazzaro F, Fratianni F, De Martino L, Coppola R, De Feo V (2013) Effect of essential oils on pathogenic bacteria. Pharmaceuticals 6: 1451 - 1474.

[23] Rachid S, Ohlsen K, Witte W, Hacker J, Ziebuhr W (2000) Effect of subinhibitory antibiotic concentrations on polysaccharide intercellular adhesion expression in 
biofilm - forming Staphylococcus epidermidis. Antimicrob Agents Chemother 44: 3357 - 3363.

[24] Sharifi - Rad J, Sureda A, Tenore GC, Daglia M, Sharifi - Rad M, Valussi M, Tundis R, Sharifi - Rad M, Loizzo MR, Ademiluyi AO, Sharifi - Rad R, Ayatollahi SA, Iriti M (2017) Biological Activities of Essential Oils: From Plant Chemoecology to Traditional Healing Systems. Molecules (Basel, Switzerland) 22: 1 - 55.
[25] Ventola CL (2015) The antibiotic resistance crisis: part 1: causes and threats. P \& T: a peer - reviewed journal for formulary management 40: 277 - 283.

[26] Winska K, Maczka W, Lyczko J, Grabarczyk M, Czubaszek A, Szumny A (2019) Essential Oils as Antimicrobial Agents - Myth or Real Alternative. Molecules 24:1 - 21.

[27] Yin W, Wang Y, Liu L, He J (2019) Biofilms: The Microbial "Protective Clothing" in Extreme Environments. Int J MolSci 20: 1 - 18. 